the least sound. On March $16 \mathrm{th}$, before commencing treatment by nerve-vibration, his pulse tracing was as follows :

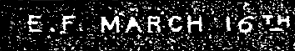

n March 21st a tracing gave this result :

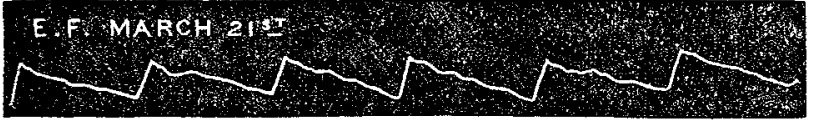

On April 3rd this patient left me practically well, with a pulse tracing which explained the improvement, thus :

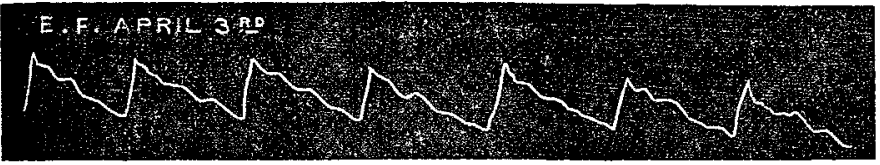

I do not wish to lay greater stress on the clinical value of the records taken by the sphygmograph in consulting practice than may be justly due. For myself I would not readily dispense with the aid afforded by that instrument in judging of the actual state of any patient. I am careful to apply it under, as nearly as possible, the same conditions of pressure and adjustment on each occasion, and I regard as important only the angle formed by the up-stroke and the decline, together with the relative proportional amplitude of the waves on the descending line as compared with the height of the up-stroke, whatever that may be. I think, however much we may differ as to the significance of the tracings given above, it will be conceded that the effect of the treatment upon the vaso-motor centre must in each instance have been marked. To this influence I attribute, in a conspicuous degree, the change effected in the general health as well as the amelioration of the particular symptoms.

In ordinary paralyses, which depend upon or are accom panied by deterioration of the muscles, I think nerve-vibration by percussion is inferior in value to electricity. In short, I do not think it has any appreciable effect except on the nerves themselves. It certainly improves the nutrition of nervous tissue, and this indirectly promotes the nutrition of muscles, but the process is circuitous and slow. Faradaism is a preferable remedy. Nerve-vibration is not the rival of electricity. The two agents act in totally different manners. Vibration simply excites a nerve centre to such activity as it may have strength or power to perform. It does not impart any new energy or introduce any new force to the system. Electricity infuses an extraneous force into the organism, but with this drawback, that it is impossible to ensure its acting only on the nerve it is desired to stimulate, and solely in such a way as to render any act of that nerve its own, and therefore normal. Vibration cannot possibly act in any other way than through the nerve or upon the centre, and, in a strict sense, nervously. One curious effect of percussion may be more interesting to the physiologist than to the practitioner, but I will place it on record. Plaving over the centre from which the nerves supplying a patticular set of muscles arise is apt to produce a feeling of fatigue or stiffness which may seem to be located in the leg or arm, although the extremity itself is not touched. This will help to explain how what is called nightmare may produce cramp, and how the activity of certain automatic centres in a wearying dream of action may give rise to a sense of fatigue on waking.

These few hints will serve to point the practitioner to a method of procedure in making trial of the remedy, but all I know of the method is at the disposal of any member of the profession who may desire to be more fully or precisely informed. I will only say, in conclusion, that I am rery hopeful that nerve-vibration will enable us to cure maladies which have hitherto been beyond remedy; and that in a certain class of cases-namely, those which require the direct stimulation of nerve-centres for their recovery-this agent will greatly help, perhaps supersede, the use of drugs.

Welbeck-street.

Soure old friends and neighbours of Dr. J. W. Cook of Manningtree have, on the occasion of his leaving the town to practise in Colchester, presented him with a silver inkstand, a purse of money, and an address as a mark of their esteem.

\section{A PECULIAR SKIN ERUPTION OCCURRING DURING PREGNANCY.}

BY R. J. W. OSWALD, L.R.C.P.ED., M.R.C.S.

THE following case may be of interest, illustrating as it does, to a certain extent, the peculiar eruption which has lately been brought into notice, and which appears only when the subject is pregnant.

Mrs. A — - aged forty, the mother of five children, was confined of a healthy male child on March $7 \mathrm{th}, 1882$. She had had no child or miscarriage for eight years and three months previously. When about five months pregnant with this last child she noticed a squamous eruption appear on the upper third of the forearms, not affecting the flexures of the elbow joints. This eruption gradually became worse, the skin was indurated and raised, and eventually both forearms and hands were affected. Almost concurrently with this the lower limbs showed the same peculiarities, with some variation, however. The enlargement was very great, almost to twice the natural size, accompanied with odema. The skin was very rough and hard, and appeared similar to "elephantiasis." About two months before the patient was confined, larger bullæe appeared on the lower extremities, but at no time were the upper limbs thus affected. Some of these bullo burst and formed hard thickened crusts, from which exuded a thin glairy fluid. The pain accompanying thfs affection was very severe, and the patient was unable to go about her household duties for fully three months previous to her confinement. Immediately after the confinement the skin of the forehead, face, neck, and upper part of the chest, which up to that time had been free from blemish, began to be squamous and indurated, and very much thickened, but no bullæ appeared at any time. Both anæsthesia and hyperæsthesia were present. She is now (seven weeks after her confinement) better in some respects, although there are still a few bullæe on the legs, and the skin still shows to a slighter extent the peculiarities just described. The patient is no doubt of a rheumatic diathesis, but whether this, combined with the great changes the system undergoes during pregnancy, has helped to cause this eruption I cannot say. The only treat. ment adopted has been absolute rest and the administration of alkalies. Previous to her confinement eicht years ago the patient had a similar eruption on the forearms and hands, and the legs and feet were affected also about two months before the confinement. In about three weeks after this the skin was quite clear again, and the severity of the attack was not nearly to the extent as in the present instance.

Kennington-road, S.E.

\section{de}

\section{HOSPITAL PRACTICE, BRITISII AND FOREIGN.}

Nulla autem est alia pro certo noscendi via, nisi quamplurimas et morborum et dissectionum historias, tum aliorum tum proprias collectas habere, et inter se comparare.-MokgaGri De Sell et Culs. Morb, lib. iv. Procmium

\section{ST. BARTHOLOMEW'S HOSPTTAL.}

STRANGULATED FEMORAL HERAIA; OPERITION; DEATH ON SEVENTH DAY; GANGRENE OF INTESTINES; PER. FORATION AND EXTRAVASATION OF FECAL MATTER.

(Under the care of Mr. WILLETT.)

THE following case, for the notes of which we are indebted to Mr. Mason, house-surgeon, presents many points of usual interest.

Mary J_, aged seventy-one, was admitted on Feb. 3rd at 4 P.M. She had had a hernia three years before, which went back without trouble, and did not return. Four days previously, in the evening, she began to be sick, and on the following morning she noticed a lump in the right groin. The sickness increased, and the night before admission became frecal. The bowels were opened last on Jan. 30th ; nothing had passed the anus since.

On examination a small, irreducible femoral hernia was 